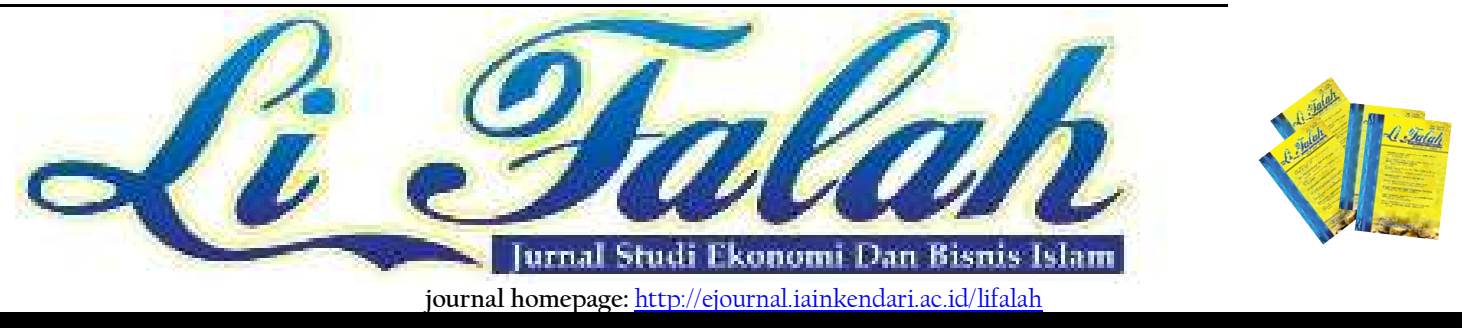

\title{
Efisiensi Bank Umum Syariah Milik Pemerintah Daerah di Indonesia
}

Muljibir Rahman ${ }^{1}$ dan Alwahidin²

'IAIN Kendari

Email: moelrohman@gmail.com

IAIN Kendari

2Email: alwahidin@gmail.com

INFORMASI ARTIKEL

Keywords: Data envelopment Analysis (DEA), Efisiensi, Bank Syariah

DOI:

http://dx.doi.org/10.31332/lifalah.v4i2.1405
A B S T R A K perbandingan tingkat efisiensi Bank Umum Syariah milik pemerintah daerah di Indonesia selama periode 2014-2018. Metode yang digunakan dalam penelitian ini adalah Data Envelopment Anaysis (DEA) dengan pendekatan intermediasi yaitu mengukur tingkat efisiensi dari masing-masing Bank Syariah dengan menggunakan metode DEA. Variabel input yang digunakan adalah jumlah simpanan,biaya tenaga kerja dan aset tetap. Sedangkan variabel output-nya adalah jumlah pembiayaan dan pendapatan operasional. Hasil penelitian DEA menunjukkan bahwa tingkat efisiensi Bank Syariah milik pemerintah daerah di Indonesia secara Overall (CRS) pada tahun 2014 sampai 2016 mencapai efisiensi yang optimum akan tetapi pada tahun 2017 dan 2018 tingkat signifikansi Bank Syariah menurun masingmasing mencapai 0,87 dan 0,93. Sementara tingkat efisiensi secara teknis (VRS) selama tahun 2014 sampai 2016 mengalami efisiensi optimum akan tetapi pada tahun 2017 mengalami penuruanan efisiensi mencapai 0,99 . Adapun penyebab utama inefisiensi sebagian pada jumlah pembiayaan, biaya tenaga kerja dan Jumlah Simpanan (Tabungan). 


\section{Pendahuluan}

Perkembangan dan pertumbuhan perbankan syariah di Indonesia diawali dengan berdirinya tiga Bank Perkreditan Rakyat Syariah (BPRS) di Bandung pada tahun 1991 dan PT BPRS Heraukat di Nangroe Aceh Darussalam. Kemudian Majelis Ulama Indonesia (MUI) melalui lokakarya "Bunga Bank dan Perbankan" di Cisarua Bogor, 18-20 1990 menjadi rapat awal pembentukan Bank Syariah di Indonesia sehingga berdirilah PT Bank Muammalat Indonesia pada tahun 1991 dan beroperasi tahun 1992 (Amir, 2010).

Perkembangan perbankan syariah di Indonesia saat ini dapat dilihat dari pertumbuhan jumlah kantor. Berdasarkan data statistik yang di keluarkan oleh Otoritas Jasa Keuangan Indoneisa (OJK) pada tahun 1999 hanya terdapat 2 bank umum syariah, 1 unit usaha syariah dan 79 bank pembiayaan syariah dengan total kantor sebanyak 122 kantor. Akan tetapi pada tahun 2018 terdapat 14 bank umum syariah, 21 unit usaha syariah dan 168 bank pembiayaan syariah dan total kantor sebanyak 318 kantor. Dari 14 Bank Umum Syariah terdapat 3 Bank Umum Syariah milik pemerintah daerah yaitu Bank Aceh Syariah, Bank Jabar dan Banten Syariah dan Bank NTB Syariah.

Berdasarkan Pasal 4 UU Nomor 21 Tahun 2008 tentang perbankan syariah, disebutkan bahwa Bank Syariah adalah badan usaha yang menghimpun dana dari masyarakat dalam bentuk simpnan dan menyalurkannya kepada masyarakat dalam bentuk kredit atau bentuk-bentuk lainnya. Maka jika dilihat dari kegiatan utama perbankan syariah perkembanganya sangat pesat terlihat dari beberapa indikator keuangan dan rasio keuangan. Berdasarkan data selama tahun 2014 sampai 2018 terjadi peningkatan pada dana pihak ketiga dan total pembiayaan.

Tabel 2 Perkembangan DPK dan Pembiayaan Tahun 2014-2018 (miliar rupiah)

\begin{tabular}{|c|c|c|c|c|c|}
\hline & 2014 & 2015 & 2016 & 2017 & 2018 \\
\hline DPK & 217.858 & 231.175 & 279.335 & 334.888 & 338.754 \\
\hline Pembiayaan & 200.177 & 213.989 & 249.087 & 286.822 & 304.674 \\
\hline
\end{tabular}

Sumber: SPS Otoritas Jasa Keuangan (OJK)

Dari tabel di atas kenaikan dana pihak ketiga atau dana yang berhasil dihimpun oleh bank syariah dari masyarakat menunjukan tren positif dengan kenaikan disetiap tahunnya. Begitupula dana yang disalurkan kemasyarakat dalam bentuk pembiayaan mengalami kenaikan dengan tren positif. 
Tabel 3 Perkembangan Kinerja Perbankan Syariah di Indonesia Tahun 2014-2018

(Dalam Persen)

\begin{tabular}{|l|c|c|c|c|c|}
\hline & 2014 & 2015 & 2016 & 2017 & 2018 \\
\hline FDR & $88,6 \%$ & $88 \%$ & $85,9 \%$ & $79,6 \%$ & $80,4 \%$ \\
\hline NPF & $4,9 \%$ & $4,8 \%$ & $4,4 \%$ & $4,7 \%$ & $3,9 \%$ \\
\hline
\end{tabular}

Sumber: SPS Otoritas Jasa Keuangan (OJK)

Dari data Finance to Deposit Ratio (FDR) diatas mengindikasikan kinerja perbankan syariah di Indonesia telah menggunakan sumber daya keuangannya (DPK) dengan baik dalam bentuk penyaluran pembiyaan kemasyarakat. Sedangkan tingkat resiko pengembalian pembiayaan dapat dilihat dari data NPF diatas mengindikasikan resiko kredit yang dihadapi oleh perbankan syariah semakin menurun artinya kinerja perbankan syariah semakin baik dalam menagih pembiayaan.

$$
\text { Meskipun perkembangan }
$$

perbankan syariah yang signifikan sesuai dengan data diatas akan tetapi pertumbuhan perbankan syariah perbulan agustus 2018 melambat dibandingkan dengan pertumbuhan perbankan syariah perbulan agustus 2017. Salah satu faktor penyebabnya adalah daya saing perbankan syariah karena didalam dualbanking system bank syariah harus berhadapan dengan bank konvensional. Salah satu aspek daya saing adalah efisiensi, inefisiensi akan menjadi kerugian besar untuk menghadapi persaingan didalam dunia perbankan. Untuk memenangkan persaingan, perbankan syariah harus lebih dahulu mengenal kekuatan dan kelemahannya dan competitor (Ascarya dan Yumanita: 2008). Maka dari itu analisis efisiensi perbankan syariah sangat penting untuk memberikan suatu gambaran kekuatan dan kelemahan diri perbankan syariah didalam menghadapi persaingan.

Perkembangan Bank Umum Syariah milik pemerintah daerah cukup signifikan, hal ini ditunjukan dengan nilai aset yang tidak kalah dengan BUS nasional lainnya. Berikut perkembangan nilai Aset BUS milik pemerintah daerah: 
Tabel 4. Jumlah Aset Bank Umum Syariah milik pemerintah daerah Tahun 2014 - 2018 (Dalam Milyar Rupiah

\begin{tabular}{|l|c|c|c|c|c|}
\hline & 2014 & 2015 & 2016 & 2017 & 2018 \\
\hline BJBS & 6,440 & 6,440 & 7,442 & 7,714 & 6,741 \\
\hline BAS & 16,385 & 18,590 & 18,759 & 22,612 & 23,095 \\
\hline \multicolumn{7}{|c|}{ Sumber: Data diolah }
\end{tabular}

Dari table di atas menunjukan bahwa perkembangan aset BUS milik pemerintah daerah tumbuh cukup signifikan ditiap tahunnya. Total aset ini dapat mengimbangi BUS Nasional lainnya, dimana pangsa pasar BUS milik pemerintah daerah hanya didominasi oleh nasabah penduduk daerah bersangkutan.

Fenomena perkembangan kinerja Bank Umum Syariah milik pemerintah daerah tersebut, dibandingkan BUS nasional yang memiliki pangsa pasar lebih luas memunculkan pertanyaan, apakah pengelolaan BUS pemerintah daerah lebih efisen dibandingkan dengan tingkat efisiensi pada Bank Umum Syariah Nasional. Penelitian ini bertujuan untuk menjawab pertanyaan penelitian tersebut.

\section{Penelitian Terdahulu dan Landasan Teori}

Hikmah dan Laila (2016) membandingkan tingkat efisiensi bank syariah di Indonesia dan Malysia dengan menggunakan metode Data Envelpoment Analysis (DEA). Variabel input dalam penelitian ini adalah Total Simpanan, Aset Tetap, Biaya Tenaga Kerja sedangkan variabel output dalam penelitian ini adalah
Total Pembiayaan dan Laba Operasional. Hasil dari penelitian ini menunjukan Bank Umum Syariah di Indonesia memiliki tingkat efisiensi dengan pendekatan intermediasi dengan asumsi CRS dan Scale Efficiency yang relatif lebih rendah namun memiliki tingkat efisiensi dengan asumsi VRS yang relative lebih tinggi bila dibandingkan dengan bank Islam di Malaysia. Hal ini menunjukan bahwa sumber inefisiensi pada Bank Umum Syariah di Indonesia bukan dikarenakan oleh pengelolaan inputnya.

Dea Anisa Miranti dan Kartika Sari (2016) dalam penelitiannya yang bertujuan untuk mengukur efisiensi Bank Umum Syariah di Inodnesia menggunakan pendekatan Data Envelopment Analysis (DEA). Objek penelitian ini adalah 11 Bank Umum Syariah selama kuartal 1 tahun 2013 sampai kuartal 1 tahun 2015. Pendekatan yang digunakan dalam penelitian ini adalah pendekatan intermediasi dan CCR output oriented. Tingkat efisiensi Bank Umum Syariah secara individu menunjukan Maybank Syariah dan Panin Syariah mampu mencapai efisiensi sebanyak lima kali selama peridoe penelitian sedangkan 
Bank lainya mengalami inefisiensi. Bank Victoria Syariah mengalami inefisiensi terendah akan tetapi memiliki trendline yang bergerak naik.

Fidaus dan Hosen (2013) dalam penelitiannya yang bertujuan untuk mengukur tingkat efisiensi Bank Syariah di Indonesia. Penelitain ini menggunakan dua metode pengukuran yaitu non parametric dengan Data Envelopment Analysis (DEA) dan parametrik dengan Regresi Tobit. Penlitian ini memberikan beberapa hasil temuan: Pertama, secara umum tingkat efisiensi 10 (sepuluh) Bank Umum Syariah memeiliki trend yang fluktiatif selama waktu penelitian secara individu Bank Muammalat Indonesia memiliki tingkat efisiensi rata-rata paling tinggi dan Bank Victoria Syariah dengan rata-rata tingkat efisiensi paling rendah. Kedua, dengan aplikasi model Tobit disimpulkan bahwa variabel Cabank Bank, Non Performing Financing (NPF) dan Capital Adequacy Ratio (CAR) memiliki pengaruh negatife dan signifikan terhadap tingkat efisiensi bank. Sedangkan pada variabel Asset dan Return On Asset (ROA) Return On Equity (ROE) memiliki pengaruh positif dan signifikan.

Penelitian yang dilakukan oleh Tofallis dan Sargeant (2000) menganalisis efisiensi relatif 327 lembaga sosial yang ada di United Kingdom. Lembaga sosial yan diteliti adalah lembaga yang memiliki biaya pengeluaran minimal $\$ 10.000$ poundsterling. Hasil penelitian menunjukkan bahwa terdapat 13 lembaga sosial yang efisien secara relatif, yakni 100 $\%$. Tercatat bahwa korelasi antara skor efisiensi dan penerimaan donasi sukarela adalah 0,34 sedangkan skor efisiensi dan biaya penghimpunan mencapai 0,18. Adapun korelasi skor efisiensi dan variable biaya administrasi adalah 0,14 . Sementara distribusi efisiensi menunjukkan bahwa lembaga sosial (charities) yang mencapai tingkat efisiensi di atas $50 \%$, hanya 49 charities ( $15 \%$ dari total).

Penelitian yang dilakukan oleh Pasiouras et.al. (2007) menganalisis tentang efisiensi Bank Koperasi di Yunani (sejenis BMT di Indonesia) selama periode 20002004. Sampel yang digunakan sebanyak 16 bank. Penelitian ini menggunakan pendekatan Two Stage DEA. Hasil penelitian menunjukan bahwa Bank Koperasi di Yunani cenderung mengalami peningkatan efisiensi biaya rata-rata sebesar 17.7\%. Kemudian hasil penelitian menggunakan Tobit menunjukkan bahwa ukuran bank berdampak positif terhadap semua pengukuran efisiensi. Sedangkan GDP perkapita berkorelasi negatif secara sigifikan.

Penelitan yang dilakukan oleh Ummi Matul Ula (2015) bertujuan untuk mengetahui seberapa efisien lembaga pengelola wakaf tunai di Indonesia. Hasil 
penelitian menunjukkan bahwa tiga lembaga pengelola wakaf tunai di Indonesia pada rentang waktu tertentu sudah berada pada tingkat efisiensi 100\% yaitu BMM pada tahun 2009 dan 2010, PKPU pada tahun 2011 dan 2013 serta TWI pada tahun 201l. Sumber inefisiensi pada lembaga pengelola wakaf tunai di Indonesia disebabkan oleh penggunaan input tidak proporsional dengan pengoptimalan yang harus dicapai untuk hasil output. Meskipun demikian, dalam performa efisiensi Return to Scale (RTS) seluruh lembaga pengelola wakaf tunai berada pada kondisi Constant Return to Scale (CRS), yang artinya setiap penambahan 1 unit input akan menambakan 1 unit output pula.

Ali dan Ascarya (2010) dalam penelitiannya menganalisis tingkat efisiensi Baitul Maal Wa Tamwil (BMT) MMU dan BMT UGT Sidogiri Pasuruan tingkat cabang dengan total sampel 50 cabang dari tahun 2005-2008. Metode yang digunakan adalah Two Stage DEA dengan pendekatan produksi. Hasil penelitian menunjukkan bahwa efisiensi overall technical BMT MMU $(0,84)$ dan BMT UGT $(0,88)$ pada tahun 2008 masih kurang optimal. Sedangkan hasil pengolahan Tobit menunjukkan bahwa kekuatan modal dan ukuran BMT memiliki pengaruh positif secara signifikan terhadap efisiensi overall technical pada dua BMT. Sementara dari sisi eksternal, PDRB perkapita memiliki pengaruh negatif secara signifikan. Adapun pertumbuhan pengangguran, tingkat pendidikan dan komitmen keberagaman tidak berpengaruh secara signifikan.

\subsection{Teori Efisiensi}

Shone Rinald menyatakan bahwa efisiensi merupakan perbandingan output dan input berhubungan dengan tercapainya output maksimum dengan sejumlah input, yang berarti jika ratio output input besar maka efisiensi semakin tinggi artinya penggunaan input terbaik dalam memproduksi output (Amirillah: 2014). Efisiensi merupakan gambaran kinerja suatu perusahaan sekaligus menjadi faktor yang harus diperhatikan bank untuk bertindak rasional dalam meminimumkan tingkat resiko yang dihadapinya(Firdaus \& Nadratuzzaman: 2013).

Efisiensi digunakan untuk menilai kinerja dalam suatu organisasi apakah dikatakan baik atau buruk suatu ukuran periode yang telah ditentukan. Sistem pengukuran penilaian kinerja seharusnya mampu memberikan penilaian yang akurat tentang seberapa baik suatu organisasi, kemudian menyediakan informasi tentang bagaimana sistem operasional pada suatu perusahaan dapat dikembangkan. Informasi tersebut dapat berupa 
bagaimana input (sumber daya) dihubungkan dengan output (produk dan jasa) yang dapat berguna dalam rangka mengidentifikasi apa yang seharusnya dilakukan (Tanjung \& Devi: 2013).

Dalam mengukur tingkat efisiensi digunakan dua pendekatan yakni pendekatan input dan pendekatan output. Pendekatan input digunakan untuk menjawab berapa banyak kuantitas input dapat dikurangi secara proporsional untuk memproduksi kuantitas output yang sama. Sedangakan pendekatan output digunakan untuk menjawab berapa banyak kuantitas output dapat ditingkatkan secara proporsional dengan kuantitas input yang sama (Tanjung \& Devi: 2013).

\subsection{Bank Syariah Sebagai Lembaga Intermediasi}

Fungsi utama dari perbankan adalah sebagai intermediasi keuangan, yakni proses pembelian surplus dana dari sektor usaha, pemerintah maupun rumah tangga, untuk disalurkan kepada unit ekonomi yang defisit(Renniwaty : 2017). Adapun proses pembelian surplus dengan menghimpun dana dalam bentuk tabungan dan deposito sedangkan proses penyaluran ke unit defisit menggunakan pembiayaan/kredit.

Adapu definsi Bank Syariah adalah bank yang beroperasi dengan tidak mengandalkan pada bunga. Dengan kata lain, Bank Islam (Bank Syariah) adalah lembaga keuangan yang usaha pokoknya memberikan pembiayaan dan jasa-jasa lainnya dalam lalu lintas pembayaran serta peredaran uang yang pengoperasiannya disesuaikan dengan prinsip syariat Islam (Antonio: 2012). Bank Syariah, selain menghindari bunga, juga secara aktif turut berpartisipasi dalam mencapai sasaran dan tujuan dari ekonomi Islam yang berorientasi pada kesejahteraan sosial (Ascarya \& Diana: 2005).

\subsection{Definisi Efisiensi}

Efisiensi adalah alat ukur untuk menilai seberapa bagus suatu organisasi mampu meminimalkan biaya dan menciptakan kekayaan atau kemampuan perusahaan dalam memanfaatkan sumber daya yang ada dengan biaya serendah mungkin dan menghasilkan output kekayaan sebanyak-banyaknya. efisiensi terdiri atas 2 unsur yaitu kegiatan dan hasil dari kegiatan tersebut. Efisiensi sendiri adalah apabila kita memasukkan suatu input tertentu maka akan menghasilkan output yang hasilnya sama dengan satu (Qurniawati : 2013)

\subsection{Teknik Pengukuran Efisiensi Menurut Coelli terdapat dua teknik pengukuran efisiensi, yakni Input Oriented Measures dan Ouput Oriented Measures (Coelli : 1988).}


a. Input Oriented Measures

Pendekatan sisi input digunakan untuk menjawab berapa banyak kuantitas input dapat dikurangi secara proporsional untuk memproduksi kuantitas output yang sama. Pendekatan input ini digunakan jika kondisi pasar sudah mengalami tingkat jenuh sehingga perusahaan perlu mengetahui tingkat efisiensi dari sumberdaya yang ada saat ini.

b. Ouput Oriented Measures

Pendekatan output digunakan untuk menjawab berapa banyak kuantitas output dapat ditingkatkan secara proporsional dengan kuantitas input yang sama. Pendekatan ini digunakan pada saat kondisi pasar masih bagus sehingga produsen diharapkan dapat mempertahankan atau bahkan meningkatkan output dan input yang sama.

\subsection{Pendekatan yang Digunakan}

Dalam mendefinisikan input dan output terdapat bermacam-macam model konseptual yang digunakan untuk membentuk sebua model efisiensi yang tepat. Berikut konsep yang sering digunakan dalam mendefinsikan hubungan input dan output dalam industri keuangan Syariah (Hadad, et al dalam Nasher: 2009):

a. Pendekatan Produksi
Pendekatan peroduksi dengan melihat Lembaga Keuangan Syariah sebagai produser dari akun deposit dan kredit Pembiyaan. Maka outpunya adalah jumlah dari akunakun tersebut atau dari transaksitransaksi yang terkait. Kemudian inputnya adalah jumlah tenaga kerja, pengeluaran modal pada asset tetap.

b. Pendekatan Intermediasi

Pendekatan ini dengan mendefinisikan Lembaga Keuangan Syariah adalah sebagai Lembaga perantara antara pihak surplus kemudian menyalurkannya kepada pihak deficit. Maka input dari pendekatan ini adalah biaya tenaga kerja, modal, pembayaran bunga pada deposito. Kemudian output dari pendekatan ini adalah kredit pinjaman dan investasi financial.

c. Pendekatan Asset

Pendekatan ini melihat fungsi primer sebuah Lembaga Keuangan Syariah sebagai penyedia pembiayaan Syariah, yang mendekati pendekatan intermediasi, dimana output benarbenar didefinisikan dalam bentuk asset-asset.

\subsection{Jenis Efisiensi}


Dalam sudut pandang perudasahaan dikenal tiga macam efisiensi, yaitu (Coelli : 1988):

1. Technical Efficiency yang merefleksikan kemampuan perusahaan untuk mencapai level output yang optimal dengan menggunakan tingkat input tertentu. Efisiensi ini mengukur proses produksi dalam menghasilkan sejumlah output tertentu dengan menggunakan input seminimal mungkin. Dengan kata lain, suatu proses produksi dikatakan efisien secara teknis apabila output dari suatu barang tidak dapat lagi ditingkatkan tanpa mengurangi output dari barang lain.

2. Allocative Efficiency, merefleksikan kemampuan perusahaan dalam mengoptimalkan penggunaan inputnya dengan struktur harga dan tekhnologinya. Terminologi efisiensi Pareto sering disamakan dengan efisiensi alokatif untuk menghormati ekonom Italia Vilfredo Pareto yang mengembangkan konsep efficiency inexchange. Efisiensi Pareto mengatakan bahwa input produksi digunakan secara efisien apabila input tersebut tidak mungkin lagi digunakan untuk meningkatkan suatu usaha tanpa menyebabkan setidak-tidaknya keadaan suatu usaha yang lain menjadi lebih buruk. Dengan kata lain, apabila input dialokasikan untuk memproduksi output yang tidak dapat digunakan atau tidak diinginkan konsumen, hal ini berarti input tersebut tidak digunakan secara efisien.

3. Economic Efficiency, yaitu kombinasi antara efisiensi teknikal dan efisiensi alokatif. Efisiensi ekonomis secara implisit merupakan konsep least cost production. Untuk tingkat output tertentu, suatu perusahaan produksinya dikatakan efisien secara ekonomi jika perusahaan tersebut menggunakan biaya dimana biaya per unit dari output adalah yang paling minimal. Dengan kata lain, untuk tingkat output tertentu, suatu proses produksi dikatakan efisien secara ekonomi jika tidak ada proses lainnya yang dapat digunakan untuk memproduksi tingkat output tersebut pada biaya per unit yang paling kecil.

\section{Metode Penelitian}


Jenis penelitian yang dilakukan pada penelitian ini adalah penelitian kuantitatif dengan pendekatan nonparametrik menggunakan metode Data Envelopment Analysis (DEA) dengan menggunakan software Banxia Frontier Analyst.

Bank Umum Syariah milik pemerintah daerah di Indonesia yaitu Bank Aceh Syariah, Bank BJB Syariah dan Bank NTB Syariah, akan tetapi peneliti hanya mengambil Bank Aceh Syariah dan Bank BJB Syariah sebagai objek penelitian ini dikarenekan Bank NTB Syariah baru saja
Konversi dari Bank NTB Konvensional pada tahun 2018 sehingga data laporan keuangan masih menyesuaikan dengan pelaporan keuangan Bank Syariah.

Data yang digunakan dalam penelitian ini adalah datas sekunder berupa time series tahunan yang didapatkan dari Laporan Keuangan tahunan masing-masing Bank Syariah di Indonesia tahun 2014, 2015, 2016, 2017 dan 2018. Dalam menentukan variabel input dan output pendekatan yang digunakan dalam penelitian ini adalah pendekatan produksi, maka berikut ini variabel input dan output dalam penelitian ini:

Tabel 4 Variabel Input dan Output

\begin{tabular}{|c|c|c|c|}
\hline \multicolumn{5}{|c|}{ Variabel Input } \\
\hline Variabel & Keterangan & Definisi & Sumber \\
\hline X1 & Jumlah Simpanan & $\begin{array}{c}\text { Total Penghimpunan Dana: Tabungan } \\
\text { Wadiah, Tabungan Giro dan Deposito }\end{array}$ & Neraca \\
\hline X2 & Biaya Tenaga Kerja & Gaji Karyawan dan Tunjangan & Laba Rugi \\
\hline X3 & Aktiva Tetap & Tanah, Gedung, kendaraan & Neraca \\
\hline Variabel & Keterangan & Variabel Output & Sumber \\
\hline Y1 & Pembiayaan & $\begin{array}{c}\text { Total Pembiyaan: Pembiayaan } \\
\text { Mudhabah, Musyarakah, Ijarah, IMBT }\end{array}$ & Neraca \\
\hline Y2 & Pendapatan Operasional & $\begin{array}{c}\text { Pendapatan Bagi Hasil, Pendapatan Jual } \\
\text { Beli dan Bonus }\end{array}$ & $\begin{array}{c}\text { Laporan } \\
\text { Laba Rugi }\end{array}$ \\
\hline
\end{tabular}

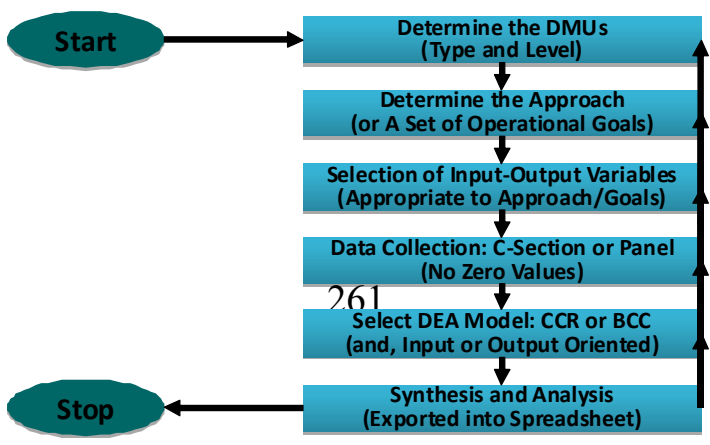




\section{Gambar 1 Tahapan Dalam Melakukan Analysis DEA}

Sumber : Ascarya (2005)

Langkah pertama yaitu menentukan DMU yang akan dijadikan objek dalam penelitian. Kemudian menentukkan pendekatan yang berfungsi untuk menyeleksi variabel input-output yang digunakan untuk penelitian. Selanjutnya memilih model DEA yang dibagi menjadi dua bagian, yaitu CCR dan BCC. Langkah terakhir adalah menganalisis dan menginterpretasi hasil analisis dari penelitian tersebut. Analisis yang dilakukan ini berdasarkan evaluasi terhadap efisiensi relatif dari DMU yang sebanding, selanjutnya DMU-DMU yang efisien tersebut akan membentuk garis frontier.Jika DMU berada pada garis frontier, maka DMU tersebut dapat dikatakan efisien relatif dibandingkan dengan DMU yang lain. Selain menghasilkan nilai efisiensi masing-masing DMU, DEA juga menunjukkan unit-unit yang menjadi referensi bagi unit-unit yang tidak efisien. Secara matematis, formulasi DEA dapat dirumuskan sebagai berikut (Ascarya, 2006):
Efficiency of DMU $=\frac{\sum_{k=1}^{p} \mu_{\mathrm{k}} \mathrm{y}_{\mathrm{k} 0}}{\sum_{i=1}^{m} v_{i} x_{i 0}}$

Keterangan:

$\mathrm{DMU}=\mathrm{UPK}$ (Unit Pengambilan Keputusan)

$\mathrm{n} \quad=$ UPK yang akan di evaluasi

$\mathrm{m} \quad=$ input-input yang berbeda

$\mathrm{p} \quad=$ output-output yang berbeda

$\mu \mathrm{k} \quad=$ rata-rata dari jumlah output

$v I \quad=$ rata-rata dari jumlah input

$\mathrm{Xij} \quad=$ jumlah input I yang dikonsumsi oleh UPKj

$\mathrm{Ykj}=$ jumlah output $\mathrm{k}$ yang diproduksi oleh UPKj

Pada pendekatan DEA terdapat dua model yang sering digunakan dalam DEA yaitu model CCR (Charnes-CooperRhodes) yang diperkenalkankan pada tahun 1978 dan model BCC (Banker, Charnes dan Cooper) yang diperkenalkan pada tahun 1984 (Coelli et.al., 2005).

\section{Hasil dan Analisis Efisiensi Perbankan Syariah}

Sebuah DMU dikatakan efisien apabila nilainya mencapai angka 100\%. Semakin rendah dari angka 100\% atau mendekati angka 0\%, maka semakin tidak efisien. Berikut ini hasil pengelohan 
efisiensi menggunakan Banxia Frontier

Anayst:

Tabel 5 Tingkat Efisiensi Bank Syariah Periode 2013 -2017

\begin{tabular}{|c|c|c|c|}
\hline BANK & $\begin{array}{c}\text { CRS } \\
\text { (overall) }\end{array}$ & $\begin{array}{c}\text { VRS } \\
\text { (teknis) }\end{array}$ & SKALA \\
\hline BAS_2014 & $100 \%$ & $100 \%$ & $100 \%$ \\
\hline BAS_2015 & $100 \%$ & $100 \%$ & $100 \%$ \\
\hline BAS_2016 & $100 \%$ & $100 \%$ & $100 \%$ \\
\hline BAS_2017 & $100 \%$ & $100 \%$ & $100 \%$ \\
\hline BAS_2018 & $95,6 \%$ & $100 \%$ & $95,6 \%$ \\
\hline
\end{tabular}

\begin{tabular}{|c|c|c|c|}
\hline BANK & $\begin{array}{c}\text { CRS } \\
\text { (overall) }\end{array}$ & $\begin{array}{c}\text { VRS } \\
\text { (teknis) }\end{array}$ & SKALA \\
\hline BJBS_2014 & $100 \%$ & $100 \%$ & $100 \%$ \\
\hline BJBS_2015 & $100 \%$ & $100 \%$ & $100 \%$ \\
\hline BJBS_2016 & $88,9 \%$ & $100 \%$ & $88,9 \%$ \\
\hline BJBS_2017 & $81 \%$ & $81,4 \%$ & $99,5 \%$ \\
\hline BJBS_2018 & $83,7 \%$ & $90,7 \%$ & $92,3 \%$ \\
\hline
\end{tabular}

Sumber : Software Banxia Frontier Analyst 4, diolah

Dari tabel diatas dapat disimpulkan terdapat 6 DMU dari 10 DMU (60\%) yang efisien secara overall (CRS) dalam mengelola bank syariah sebagaimana fungsinya yaitu lembaga intermediasi, 30 DMU ini memiliki skala usaha yang konstan artinya jika DMU tersebut menambah input sebesar $n$, maka output akan bertambah sejumlah n. Kemudian secara teknis terdapat 8 DMU (80\%) yang efisien (VRS) dan secara skala terdapat 6 DMU (60\%) yang efisien dalam pengelolaanya. Oleh karena itu, masih banyak dari beberapa DMU yang belum menjalankan fungsinya secara optimal sehingga harus meningkatkan efisiensi dalam pengelolaannya. Secara teknis hampir semua Bank Umum Syariah milik pemerintah daerah mencapai efisien hanya Bank BJBS tahun 2017 dan 2018 tidak mencapai efisien hal ini disebakan oleh kenaikan pada variabel aktiva tetap yang tidak dapat dimakasimalkan untuk meningkatkan pendapatan operasional. Secara umum tingkat efisiensi Bank Umum Syariah milik pemerintah daerah dapat dilihat pada gambar berikut: 


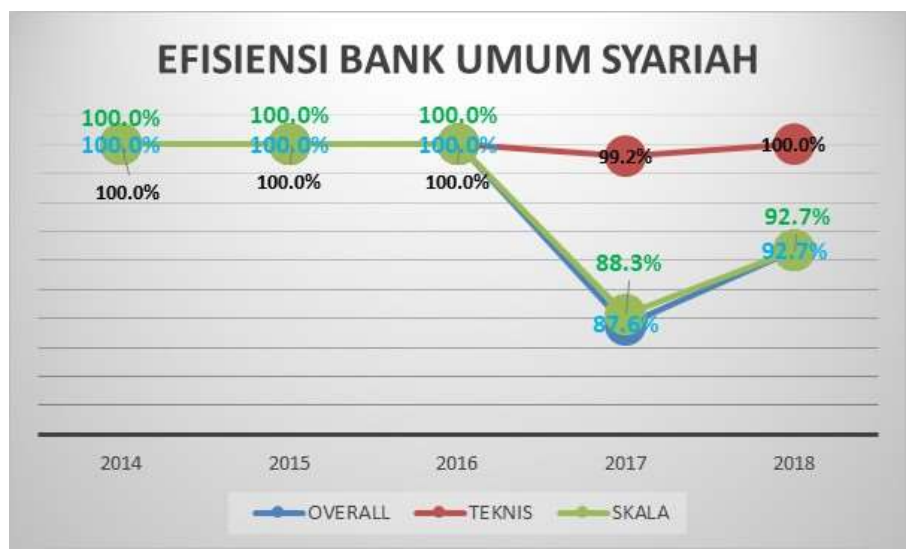

Gambar 2. Efisiensi Bank Umum Syariah Milik Pemerintah Daerah

\begin{tabular}{|c|c|}
\hline \multicolumn{2}{|r|}{$\begin{array}{l}\text { Oleh karena itu, suatu DMU setiap } \\
\text { tahunnya akan memiliki salah satu dari tiga }\end{array}$} \\
\hline pemerintah daerah secara Overall pada & ondisi Return to Scale (RTS) diantaranya \\
\hline tahun 2014-2016 menunjukan kinerja yang & Constant Return to Scale (CRS), \\
\hline optimal akan tetapi pada tahun 2017 - 2018 & ncreasing Return to Scale (IRS) dan Decreasing \\
\hline menunjukan kinerja yang kurang efisien & Return to Scale (DRS). Constant Return to Scale \\
\hline hal ini disebabkan Aktiva tetap yang & (CRS) merupakan suatu keadaan dimana \\
\hline kurang optimal digunakan untuk & ketika ada perubahan atau penambahan \\
\hline menghasilkan output, kemudian & pada satu persen unit input tertentu maka \\
\hline banyaknya Jumlah Simpanan yang tidak & akan mengakibatkan perubahan pada \\
\hline disalurkan. Kemudia secara efisiensi teknis & output yang besarnya sama dengan \\
\hline 2014-2016 menunjukan kinerja yang & persentasi perubahan input. Sementara \\
\hline optimal, walaupun pada tahun 2017 sempat & Increasing Return to Scale (IRS) adalah \\
\hline mengalami penurunan pada 0,99 akan & keadaan dimana ketika ada perubahan atau \\
\hline tetapi kembali memberikan performa yang & penambahan pada satu persen unit input \\
\hline baik pada tahun 2018 & tertentu maka akan mengakibatkan \\
\hline Metode DEA selain untuk & perubahan pada output yang besarnya lebih \\
\hline mengukur DMU mana yang efisien dan & dari satu persen. Sedangkan Decreasing \\
\hline inefisien, metode ini juga mampu & Return to Scale (DRS) adalah keadaan \\
\hline mengukur seberapa optimal penggunaan & dimana ketika ada \\
\hline input dalam menghasilkan output, dimana & penambahan pada satu persen unit input \\
\hline suatu DMU dapat menunjukkan & tertentu, maka \\
\hline ptimalisasi dalam kapasitas produ & perubahan pada output yang besarnya \\
\hline
\end{tabular}


kurang dari persentasi perubahan pada input tertentu (Ascarya, 2008).

4.1 Efisiensi Pengelolaan Bank Aceh Syariah dan Potensi Perbaikannya

Bank Aceh Syariah adalah bank syariah milik Pemerintah Daerah Nangroe
Aceh Darussalam memiliki jumlah simpanan dan asset terbesar dibanding dengan Bank Jabar Banten Syariah, hal ini membuktikan bahwa Bank Aceh Syariah mendapat kepercayaan yang besar dan dukungan penuh dari masyarakat Aceh.

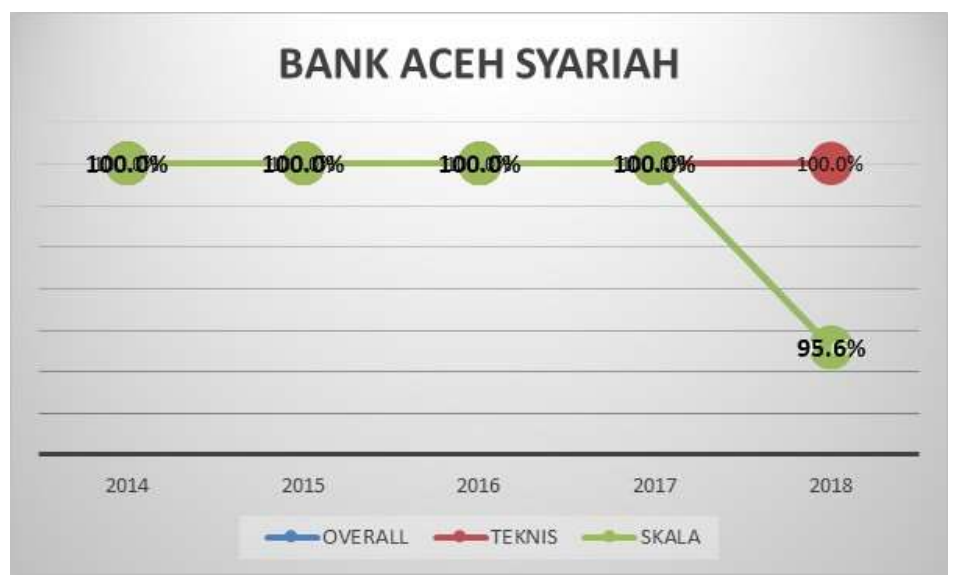

Gambar 3. Efisiensi PT Bank Syariah Mandiri

Sumber : Software Banxia Frontier Analyst 4, diolah

Berdasarkan gambar diatas secara teknik efisiensi Overall, teknis dan skala bank syariah ini memiliki kinerja keuangan disetiap tahunya dengan konsisten mempertahankan efisiensi didalam pengelolaan keuangannya. Akan tetapi pada tahun 2018 secara overall dan skala tidak menunjukan efisiensi dalam pengelolaanya, maka perlu dilakukan perbaikan-perbaikan. Sumber informasi tersebut dapat dilihat pada table berikut ini: 


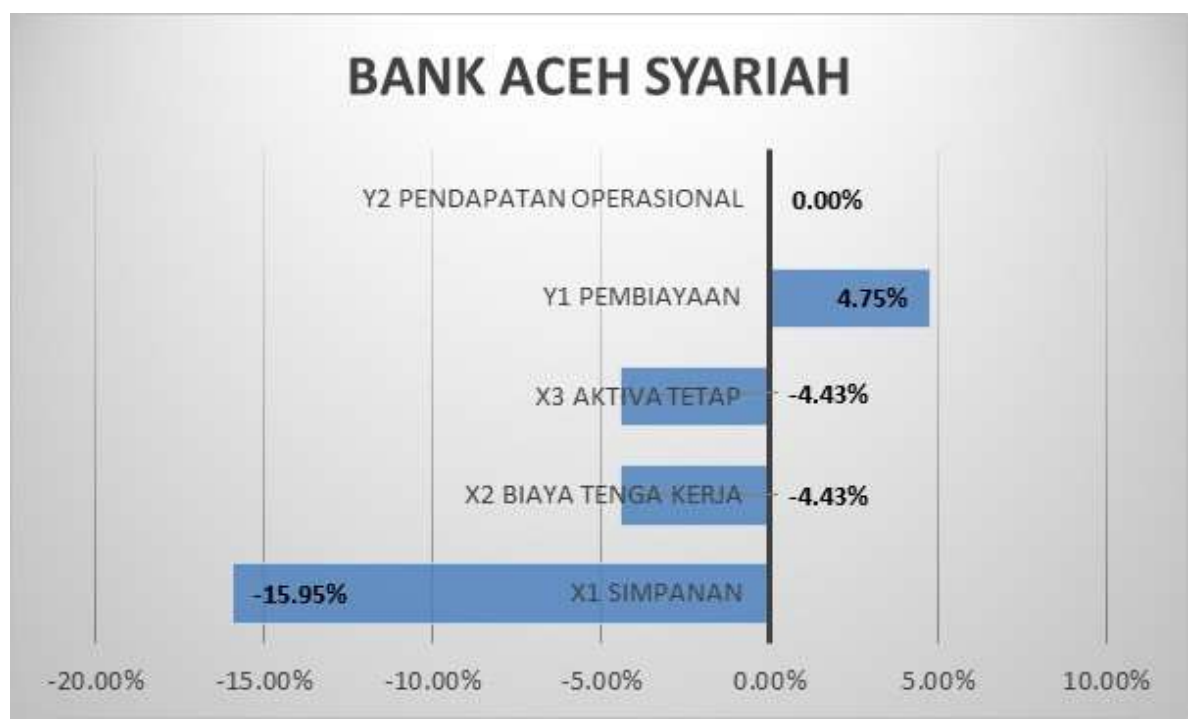

Gambar 4. Potensi Perbaikan Efisiensi Bank Aceh Syariah Tahun 2018

Dari gambar diatas dapat disimpulkan bahwa untuk mencapai efisiensi pada tahun 2018 Bank Aceh Syariah harus menekan penyaluran dana simpanan sebesar 15,95\% dikarenakan penyaluran dana simpanan yang terlalu ekspansif akan berpotensi resiko gagal bayar. Kemudian Bank Aceh Syariah harus mengurangi Biaya Tenaga Kerja sebesar $4,43 \%$ dikarenakan akan menggerus keuntungan bersih Bank, serta variabel Aktiva tetap harus dikurangi sebesar 4,43\% artinya Bank Aceh Syariah harus memaksimalkan asset tetap untuk mendapatkan pendapat operasional. Dari sisi output Bank Syariah ini memiliki potensi penyaluran dana sebesar 4,75\% dari nilai rata-rata perbulannya untuk mendapatkan efisiensi yang optimal.

\subsection{Efisiensi Pengelolaan BANK BJB Syariah dan Potensi Perbaikannya}




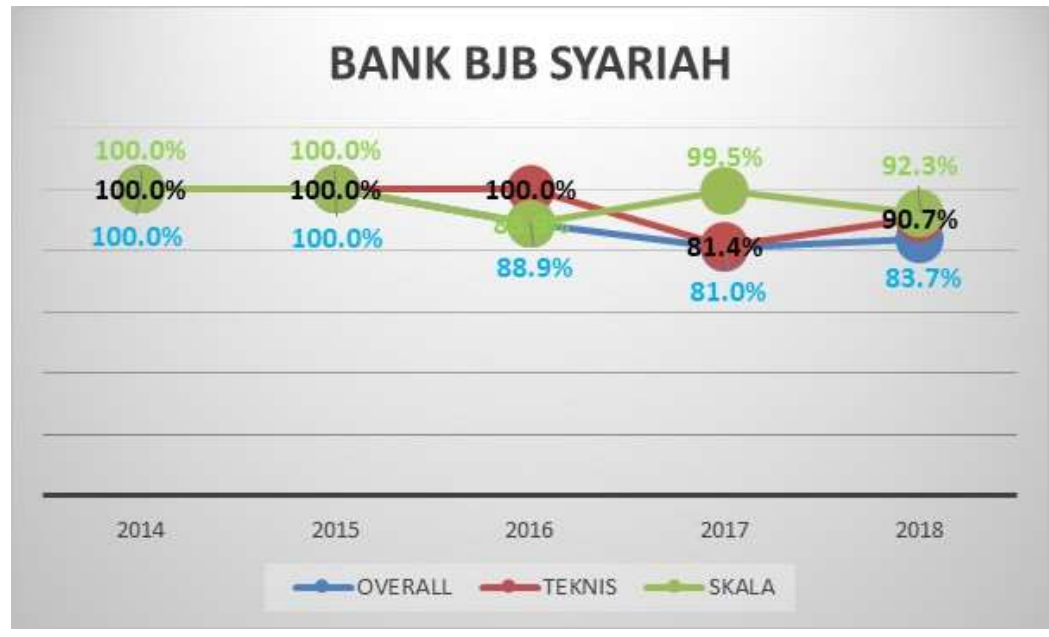

Gambar 5. Efisiensi Bank BJB Syariah

Berdasarkan gambar diatas pada tahun 2014 dan 2015 Bank BJB Syariah menunjukan kinerja yang optimal dengan pencapaian efisiensi baik secara overall, teknis dan skala. Kemudian pada tahun 2016 secara teknis masih dalam keadaan yang optimal akan tetapi secara overall dan skala mengalami inefisiensi, selanjutnya diikuti pada tahun 2017, 2018 dan 2019. Maka adapun hal-hal yang perlu dilakukan perbaikan pada tahun tersebut adalah sebagai berikut:

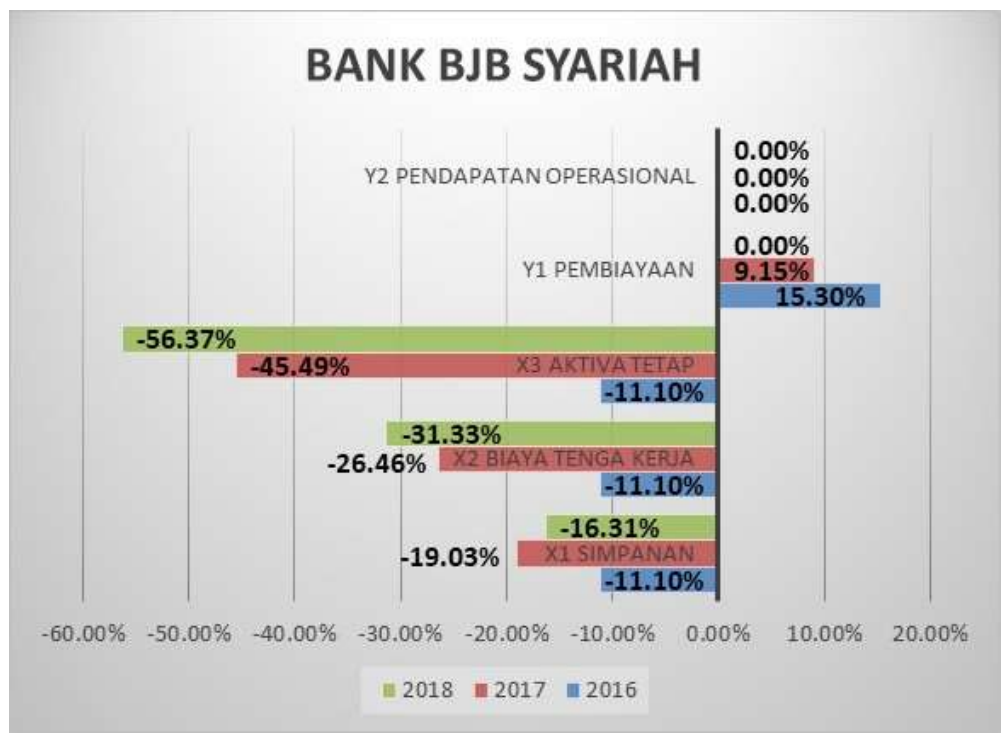

Gambar 6. Potensi Perbaikan Efisiensi Bank BJB Syariah 
Dari gambar diatas pada tahun 2016 Bank BJB Syariah harus melakukan beberapa improvement yaitu: Variabel Pembiyaan memilik potensi pengembangan sebesar $15,3 \%$ artinya output ini harus ditingkatkan dengan memakasimalkan penyaluran pembiyaan sebesar $15,3 \%$ dari rata-rata setiap bulannya. Kemudian untuk varibel input Bank BJB Syariah yaitu Simpanan, Biaya Tenaga Kerja dan Aktiva Tetap memiliki potensi pengembangan sebesar 11,1\% artinya Bank BJB Syariah harus mengurangi Penghimpunan dana, biaya tenga kerja dan Aktiva tetap sebesar 11,1\% dari rata-rata perbulan pada tahun 2016.

Kemudian pada tahun 2017 Bank BJB Syariah mempunyai potensi pengembangan pada variabel Pembiyaan sebesar 15,30\% artinya Bank BJB Syariah harus meningkatkan pembiyaan sebesar $15,30 \%$ untuk mencapai efisiensi yang optimal. Untuk varibal input Bank BJB Syariah memiliki potensi pengembangan pada varibel Simpanan Sebesar 19,03\%, Biaya Tenaga Kerja sebesar 26,46\% dan Aktiva Tetap sebesar 45,46\% artinya pada variabel simpanan harus dikurangi sebesar 19,03\%, kemudian varibel biaya tenaga kerja harus dikurang sebesar $26,46 \%$ dan variabel aktiva tetap harus dikurangi sebesar 45,46\% untuk mencapai kinerja yang optimal.
Kemudian pada tahun 2018 Bank BJB Syariah mempunyai potensi pengembangan pada varibal input saja, Bank BJB Syariah memiliki potensi pengembangan pada varibel Simpanan Sebesar 16,31\%, Biaya Tenaga Kerja sebesar 31,33\% dan Aktiva Tetap sebesar $56,37 \%$ artinya pada variabel simpanan harus dikurangi sebesar 16,31\%, kemudian varibel biaya tenaga kerja harus dikurang sebesar 31,33\% dan variabel aktiva tetap harus dikurangi sebesar 56,37\% untuk mencapai kinerja yang optimal.

Satu keunggulan yang dimiliki oleh DEA adalah dapat membuat peringkat DMU yang dapat dijadikan Brenchmark bagi DMU lainnya. Dalam hal ini, dapat memberikan informasi Bank Umum Syariah milik pemerintah daerah yang paling banyak dirujuk oleh BUS Lain yang tidak efisien selama tahun 2014 - 2018. Gambar dibawah ini menunjukan bahwa pada tahun 2015 BUS milik pemerintah daerah yang paling banyak dijadikan referensi adalah Bank BJB Syriah yakni sebanyak 4 kali kemudian diikuti oleh Bank BJB Syariah pada tahun 2014 sebanyak 4 kali. Afrtinya Bank BJB Syariah pada tahun 2014 dan 2015 mencapai titik efisiensi yang optimum dibanding dengan tahun-tahun lainnya dan dari Bank Umum Syariah milik pemerintah lainnya yang inefisiensi. Inefisiensi dapat disebabkan 
oleh penggunaan input yang berlebihan atau pencapaian output yang masih minim.

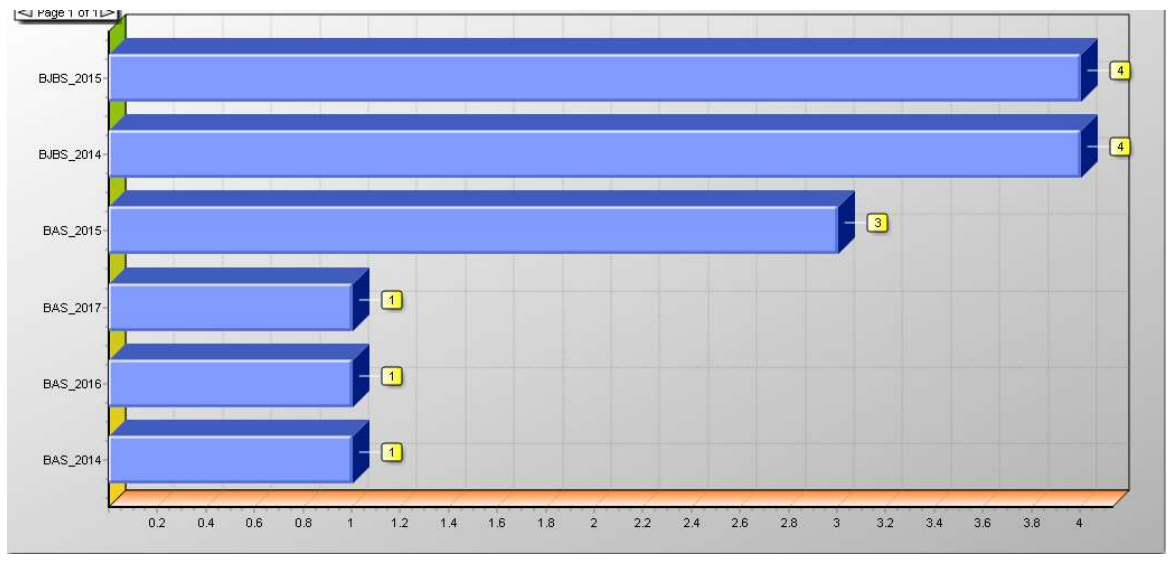

Gambar 7. DEA Reference Set

\section{Penutup}

\subsection{Kesimpulan}

Tujuan penelitian ini adalah untuk mengetahui kinerja efisiensi Bank Umum Syariah milik pemerintah daerah di Indonesia. Setelah melakukan pengolahan data dan menganalisis hasilnya, maka penulis dapat memberikan beberapa kesimpulan:

a. Meneurut teknik efisiensi teknis (VRS) Bank Aceh Syariah sudah mencapai efisiensi disetiap tahunya, akan tetapi menurut efisiensi Overall dan Skala Bank Aceh Syariah mengalami inefisiensi pada Tahun 2018 sebesar 95,6\%.

b. Bank BJB Syariah secara berturutturut pada tahun 2014-2015 mencapai kinerja yang optimal baik secara Overall, Teknik maupun Skala akan tetapi ditahun 2016 hanya efisiensi teknis saja yang menunjukan kinerja yang optimal sedangkan efiseinsi Overall dan Skala belum menunjukan kinerja yang optimal.

c. Secara efisiensi overall dan skala gabungan kedua Bank Umum Syariah milik pemerintah daerah ini pada tahun 2014-2016 mengalami efisiensi atau menunjukan kinerja yang optimal akan tetapi pada tahun 2017-2018 tidak menunjukan kinerja yang optimal. Adapun secara teknis hanya pada tahun 2017 saja Bank Umum Syariah ini tidak berada dalam kinerja yang optimal. 


\subsection{Keterbatasan Penelitian}

Penulis menyadari bahwa penelitian ini memiliki banyak kekurangan dan masih jauh dari kesempurnaan. Keterbatasan dalam penelitian ini antara lain:

a. Masih kurangnya penelitian terdahulu mengenai efisiensi Bank Umum Syariah, sehingga konsep efisiensi dalam penelitian ini belum matang diakarenakan dibutuhkan penelaahan yang mendalam tentang konsep efisiensi dalam Bank Umum Syariah terhkhusus Bank Umum Syariah milik pemerintah daerah

b. Jumlah observasi masih sangat sedikit, hal ini disebabkan jumlah Bank Umum Syariah pemerintah daerah masih sangat sedikit.

c. Penelitian ini hanya mengukur tingkat efisiensi Bank Umum Syariah milik pemerintah daerah tanpa mengukur faktor-faktor yang mempengaruhi inefesiensi tersebut.

\subsection{Saran dan Rekomendasi}

Berikut beberapa rekomendasi yang penulis berikan:

a. Kepada Bank Umum Syariah milik pemerintah daerah agar selalu menjaga stabilitas kinerja yang telah efisien sebelumnya. Kemudian mengurangi Aktiva tetap sebesar 35,4\%, Biaya Tenaga Kerja sebesar 7,35\% dan Simpanan $\quad 15,92 \% \quad$ sedangkan penghimpunan dana dapat ditingkat sebesar $14,33 \%$.

b. Kepada Bank Pemerintah Daerah untuk mempertimbangkan konversi BPD menjadi Bank Umum Syariah melihat konsistensi efisiensi Bank Umum Syariah milik pemerintah daerah. 
DAFTAR PUSTAKA

Al-Qur'an Al-Karim dan Terjemahnya. 2006. Jakarta: Maghfirah Pustaka.

Abdelkader, I. B., Hathroubi, S. \& Jemaa, M. M. 2014. "Microfinance Institutions Efficiency in the MENA Region: a Bootstrap-DEA Approach". Research Journal of Finance and Accounting, Vol.5, No.6, 179-191.

Akbar, Nasher. 2009. "Analisis Efisiensi Organisasi Pengelola Zakat Nasional dengan Pendekatan Data Envelopment Analysis". Tazkia Islamic Finance o Business Review. Vol.4, No.2.

Ali, M. dan Ascarya. 2010. "Analisis Efisiensi Baitul Mal wa Tamwil dengan pendekatan Two Stage Data Envelopment Analysis (Studi Kasus Kantor Cabang BMT MMU dan BMT UGT Sidogiri). Tazkia Islamic Finance $\sim$ Business Review. Vol.5, No.2, August-December, 110-125.

Antonio, M. Syafi'i. 2001. Bank Syariah dari Teori ke Praktik. Edisi Pertama. Jakarta: Gema Insani Pess.

Ascarya dan Yumanita, Diana. 2005. "Analisis Efisiensi Perbankan Syariah di Indonesia". Pusat Pendidikan dan Studi Kebanksentralan Bank Indonesia.

Ascarya, et.al. 2007. "Measuring the Efficiency of Conventional and Islamic Banks in Indonesia and Malaysia”. CCBES (Center for Central Banking Education and Studies).

Ascarya dan Yumanita, Diana. 2009. "Analisis Efisiensi Intermediasi Bank Perkreditan Syariah di Indonesia: Pendekatan Two Stage DEA, Draft. Jakarta: PPSK Bank Indonesia.

Biro Administrasi Perekonomian Sekretariat Daerah Provinsi Jawa Timur. 2016. Data Dinamis
Perekonomian Jawa Timur Maret 2016. Jawa Timur

BPS Kota Bandung. 2016. Produk Domestik Regional Bruto Kota Bandung Menurut Lapangan Usaha 2011-2015. Katalog BPS No: 9205. 3273. Bandung.

BPS Kabupaten Kuningan. 2016. Produk Domestik Regional Bruto Kabupaten Kuningan Menurut Lapangan Usaha 2011-2015. Katalog BPS No: 9305. 3208. Kuningan.

BPS Kota Tasikmalaya. 2016. Produk Domestik Regional Bruto Kota Tasikmalaya Menurut Lapangan Usaha 2011-2015. Katalog BPS No: 9205. 3278. Tasikmalaya.

BPS Kabupaten Tasikmalaya. 2016. Produk Domestik Regional Bruto Kabupaten Tasikmalaya 2011-2015. Katalog BPS No: 9302008. 3206. Tasikmalaya

Chang, T. C. and Chiu, Y. H (2006). "Affecting Factors on risk-adjusted Efficiency in Taiwan's Banking Industry". Contemporary Economic Policy, Vol. 24, Issue 4, 634-648.

Cooper, W. William, Seiford, M dan Zhu Joe. 2006. Data Envelopment Analysis History, Models and Interpretations. Red McCombs School of Business. University of Texas at Austin. TX 78712 USA.

Coelli, et.al. 2005. Introduction to Efficiency and Productivity Analysis. Kluwer Academic Publisher. Boston.

Dzanuryadi, M. 2011. Goes To Pesantren Panduan Lengkap Sukses Belajar di Pesantren. Cetakan Pertama. Jakarta: Lingkar Pena.

Deelchand dan Padgett. 2009. "Relationship between Risk, Capital and Efficiency: Evidence from Japanese Cooperative Banks". ICMA Centre Discussion Papers in Finance DP2009-12. Henley University of Reading: Finlandia.

Departemen Agama RI, Direktorat Jenderal Bimbingan Masyarakat Islam, Direktorat Pemberdayaan Wakaf, 
Bunga Rampai Perwakafan. 2006. Jakarta: Depag RI.

Departemen Agama RI, Direktorat Jenderal Bimbingan Masyarakat Islam, Direktorat Pemberdayaan Wakaf. 2013. Pedoman Pengelolaan dan Perkembangan Wakaf. Jakarta: Depag RI.

Endri. 2011. "Evaluasi Efisiensi Teknis Perbankan Syariah di Indonesia: Aplikasi Two Stage DEA". Jurnal STEI TAZKIA.

Farrell, M. L. 1957. "The Measurement of Productive Efficiency". Jurnal of The Royal Statistical Societi. 120,p. 253281.

Gujarati, D. N. 1995. Basic Econometrics. Third Edition. McGraw-Hill International.

Hasanah, Uswatun. 1997. "Peran Wakaf dalam Mewujudkan Kesejahteraan Sosial Studi Kasus Pengelolaan Wakaf di Jakarta Selatan". Disertasi. Jakarta: UIN Syarif Hidayatullah.

Huda, Miftahul. 2012. "Wakaf dan Kemandirian Pesantren dari Tebuireng hingga Gontor". Islamica. Jurnal Studi Keislaman, Vol.7 No.l hal. 27l. Edisi September.

Holly, Najoan. 2016. "Analisis Kinerja

Perbankan Ditinjau dari Aspek Profitabilitas dan Efisiensi (Studi Kasus Pada Bank yang Terdaftar di BEI Periode 2012-2014). Jurnal Riset Bisnis dan Manajemen Vol. 4, No. 3, Edisi Khusus Pemasaran \& Keuangan 2016: 407-420. Manado.

Al-Imam Fida Abul Isma'il Ibnu Kasir AdDimasyqi. Tafsir Al-Qur'an Al'Adzhim. Diterjemahkan Bahrun Abu Bakar. 2000. Tafsir Ibnu Katsir. Bandung: Sinar Baru Algensindo.

Jamaluddin, Malik. 2005. Pemberdayaan Pesantren Menuju Kemandirian dan Profesionalisme Santri. Yogyakarta: Pustaka Pesantren. Cet. Ke-1,hl.
Kahf, Monzer. 2000. Al-Waqf Al-Islam Tathawwaruh, Idaratuh, Tanmiyatuh. Damaskus: Dar Al-Fikr.

Karim, Adiwarman. 2004. Bank Islam: Analisis Figh dan Keuangan. Jakarta: PT. Raja Grafindo Persada.

Karim, Adiwarman. 2012. Ekonomi Mikro Islam. PT. Raja Grafindo Persada. Jakarta.

Masruchin. 2014. "Wakaf Produktif dan Kemandirian Pesantren". Tesis Program Studi Ilmu Ekonomi Shari'ah, UIN Sunan Ampel. Surabaya.

Mastuhu. 1994. Dinamika Sistem Pendidikan Pesantren Suatu Kajian Tentang Unsur dan Nilai Sistem Pendidikan Pesantren. Edisi Pertama. Jakarta: INIS.

Matul, U. Ula. 2015. "Analisis Efisiensi Lembaga Pengelola Wakaf Tunai di Indonesia". Jurnal Ekonomi, Fakultas Ekonomi dan Bisnis Universitas Brawijaya. Malang.

Mubarok, Jaih. 2008. Wakaf Produktif. Bandung: Simbiosa Rekatama Media.

Mujamil Qomar. 2009. Pesantren Dari Transformasi Metodologi Menuju Demokrasrisasi Institusi. Jakarta: Erlangga, h.2.

Pasiourus, Fotios. 2007. "Estimating the technical and scale efficiency of Greek commercial bank: The impact of credit risk, off balance sheet activities and International operation". Papers. University of Bath, School of Management, United Kingdom.

Qahaf, DR. Mundzir. 2005. Al-waqfu AlIslami. Dar Al-Fikr Damaskus. Diterjemahkan Muhyiddin M. Rida. Manajemen Wakaf Produktif. Jakarta: Khalifa (Pustaka Al-Kautsar Grup).

Ruslan Abdul Ghofur. 2012. "Kebijakan Distribusi Ekonomi Islam dalam Pembangunan Keadilan Ekonomi Indonesia". E-Journal IAIN Sunan Ampel. Islamica Vol 6, Maret. 
Rozalinda. 2015. Manajemen Wakaf Produktif. Jakarta: PT. Raja Grafindo Persada.

Rukminastiti, A. Masrifah. 2016. "Efisiensi BMT Pesantren dalam Pengelolaan Harta Usaha Mikro". Tesis Program Pascasarjana Magister Ekonomi Syariah STEI Tazkia. Bogor.

Sudarsono, Heri. 2002. Konsep Ekonomi Islam. Yogyakarta: Ekonisia.

Suhadi, Imam. 2002. Wakaf Untuk Kesejahteraan Umat. Edisi Pertama. Yogyakarta: PT. Dana Bhakti Prima Jasa.

Sutrisno. 2015. Islamic Wealth Management Slides. Pascasarjana STEI Tazkia. Bogor.

Tessa dan Ricky. 2011. "Technical Efficiency of Indonesian Commercial Banks: An Application of Two Stage DEA". Jurnal Manajemen dan Kewirausahaan, Vol. 13, No. 2, September 2011: 107-116.

Tofallis, Chris \& Sargeant, Adrian. 2000. "Assesing Charities Using Data Envelopment Analysis". Center for Business Performance. University Cranfield.

Umar, N. 2014. Rethinking Pesantren. Jakarta: Kompas Gramedia.

Zamil, Nor Aiza Mohd., Abdul Rahim Abdul Rahman. 2006. "Efficiency of Islamic and Conventional Commercial Banks in Malaysia: A Data Envelopment Analysis (DEA) Study". Paper, Institute of Islamic Banking and Finance (IIBF), IIUM. Malaysia.

Zarkasyi, S. A. 2005. Gontor dan Pembaharuan Pesantren. Edisi Pertama. Jakarta: PT. Raja Grafindo Persada.

Ziemek, Manfred Dhofier. 1986. Pesantren dalam Perubahan Sosial. Perhimpunan Pengembangan Pesantren dan Masyarakat (P3M). Jakarta.

Az-Zuhaili, Wahbah. 201l. Fiqih

Islam Wa Adillatuhu. Jilid 10 Darul Fikr.

Jakarta: Gema Insani. 